\title{
Minority Discontent as an Internal Destabilization Factor: The Issue of Territorial Minorities in Bosnia and Herzegovina
}

\section{Introduction}

Often referred to as "Yugoslavia in miniature", Bosnia and Herzegovina (BiH), a small state at the heart of the Balkan Peninsula, can rightfully be considered a country of minorities. The reasons for this are manifold, but most can be traced back to the country's post-Second World War history, which from 1945 until 1991 was part of the Socialist Federal Republic of Yugoslavia ${ }^{1}$. Yet, the colorful ethno-national picture of $\mathrm{BiH}$ is a difficult case for the stability theories. The consociational political system that was instituted in Bosnia and Herzegovina in 1995 by the Dayton Peace Agreement, reflects, or more so, mirrors the segregation of BiH's citizens in everyday life. Caught in a limbo of queries pertaining to their majority-minority statuses, the citizens of $\mathrm{BiH}$ can be well defined as either a majority or a minority, depending on where they go or, better, reside. Subject to different ethno-national

${ }^{1}$ From 29 November 1945 until 7 April 1963 Yugoslavia was called the Federal People's Republic of Yugoslavia (Federativna Narodna Republika Jugoslavija, FNRJ) when it changed its name to the Socialist Federal Republic of Yugoslavia (Socijalistička Federativna Republika Jugoslavija, SFRJ). 
(often nationalistic) rhetoric, the issue of who can be considered a minority and where, lies at the core of Bosnia's many social ills. Not only does this problem penetrate the lives of ordinary men, but rather takes a different form once it reaches the "power-sharing realm", where the issue of minorities ${ }^{2}$ becomes a state stability issue.

When examining the "minority status" issue within broader communities in $\mathrm{BiH}$, it becomes rather clear that the question of minorities is saturated with both political and social significance. And while the country continues to enjoy peace, the legacies of the Dayton era still hold an unyielding grip over contemporary social policies and power-sharing politics, both of which severely underscore country's internal stability. Despite the fact that Dayton Accords were designed with the ultimate aim to end the war, the unintended consequence of the constitutional arrangement was to institutionalize the historical divisions. In the context of stability, this meant granting a right to ethnic entrepreneurs to propagate exclusive, rather than integrationist political agendas. Thus, the consociational arrangement proposed by Dayton Constitution, notably on the decision-making level, echoes societal divisions at other levels, hence penetrating into the citizen's realm. This is precisely why the issue of minority statuses is politicized on all levels even among the ordinary citizens, a factor that underpins socio-political instability in $\mathrm{BiH}$.

Understanding the patterns of internal stability in the democratic context might be an easy task, but when

${ }^{2}$ For the purposes of introducing this complex constellation, a general term "minorities" is used in the introduction in order to enunciate the scope of the issues, or the fact that both national and territorial/statistical/constituent minorities face the same issue. All of these terms will be dealt with separately later in the study. 
considering a post-conflict and a failed state it tends to become a "mission impossible". This is especially so in $\mathrm{BiH}$, whose internal stability is shattered mostly due to the overly politicized issue of territorial belonging, statistical data and ethnic background, all of which are factors that contribute to the endless debate of who and where is one a minority. Thus, this paper comprehensively investigates the current impact of the Dayton imbedded concept of ethnicity which strengthens ethnic belonging and overemphasizes the concept of territorial or constituent minorities in $\mathrm{BiH}$. It argues that statistical differences in the number of constituent peoples across the country significantly contribute to state's shattered internal stability, overstressing and strengthening the pre-existing nationalistic discourses and creating space for new, but pre-war inspired rhetoric. The analysis is presented through an investigation of the impacts that this issue has on two separate domains of the socio-political life in $\mathrm{BiH}$ - the power-sharing and the citizens' realms.

\subsection{Who are the "Constituents" and who are the "Others"? Revisiting the Minority Dilemma in the Context of Post-War BiH}

In $\mathrm{BiH}$, political representation rests on the concept of "differentiated citizens", where identity (ethnic, cultural or religious) plays an enormous role in the process of decision-making and participation. In the post-war period, the dilemma of who can be considered a minority escalated to a point where the term "minority", as understood by most European democratic countries, started being severely 
abused; each group, despite its constitutional status ${ }^{3}$, adopted the use of the term solely under the umbrella of their territorial and/or statistical (under) representation. In this constellation of events it is easy to understand how such territorial and statistical disputes cause an almost artificial sense of crisis, which often escalate into conflicting debates and result in talks where words such as "secession", "referendum" and "underprivileged" are omnipresent.

Thus, in order to better understand and analyze the correlation between the term "minority" and the implications that it has for the internal stability of the post-war $\mathrm{BiH}$, one will systematically examine the three theoretical explanations of the term, which take into account the statistical, socio-political and legal factors, but also the peculiarities of each group, including those characteristics which describe identity and time and spatial presence ${ }^{4}$. All of these dimensions are essential in understanding many gaps in interpreting the statuses and rights of both de facto and de jure minorities in $\mathrm{BiH}$, but also in bridging their discontent to the issue of internal stability.

\subsubsection{The Statistical Approach}

According to the statistical approach to the concept of minorities, for a group to be termed a minority it has to be numerically smaller compared to the rest of the population.

${ }^{3}$ It can be said that the Bosniaks, Serbs and Croats have a preferential constitutional status over "Others", as they have been granted the ultimate rights to participate in the decision-making on the highest level, as well as to be elected. This is not so for the underprivileged "Others".

${ }^{4}$ E. Hodžić, N. Stojanović, Novi-stari ustavni inžinjering? Izazovi i implikacije presude evropskog suda za ljudska prava u predmetu Sejdić $i$ Finci protiv BiH, Sarajevo 2011, p. 43. 
Hence, a statistical minority is a group which accounts for less than $50 \%{ }^{5}$ of the entire population. However, the statistical approach does not encompass just merely numbers, but takes into account the three essential dimensions of the term "minority" per se, thus examining:

a) The identity criteria;

b) The moment of observation (time variable);

c) Territorial presence (spatial variable).

The above criteria are, than, further divided according to the sub-traits of each dimension, for it is precisely from these subdivisions that we can examine, in greater detail, the peculiarities of each case.

The identity criteria is probably the broadest one, encompassing traits which include permanent (descriptive) and contingent (dependent) characteristics. Thus, permanent attributes include differences in gender, skin color, and eye shape and all other birth-given or physical attributes which cannot be changed (or are difficult to change). The contingent characteristics, on the other hand, include all those personal traits which are much easier adjusted, including citizenship and ideological orientation. The contingent characteristics are not imbedded in an individual by birth, but are brought on by outside factors, such as education, socio-political circumstances at any given period of life or even economic aspects.

Nevertheless, in some societies language and religion are seen as hereditary traits, as something that stays with an individual for the rest of his/her life. This is certainly the case in $\mathrm{BiH}$, where the issue of language is not so relevant (considering that both territorial and national minorities ${ }^{6}$

\section{${ }^{5}$ Ibidem, p. 44.}

${ }^{6}$ This statement does not apply to national minorities who converse in their minority language within their closed communities (e.g. Roma in 
speak a variant of the same language and that it is difficult to pinpoint to their ethnic background just from their accent), but the religious factor is the underlying characteristic of all communities, as it used as the main denominator of one's ethnic background. What is more, religion in $\mathrm{BiH}$ is inseparable from identity claims, and as such can be considered as the main destabilizing factor, at least within the citizen's realm. Thus, religion (and language) are not contingent, but rather permanent ethnic traits which are brought from generation to generation. Then, to no wonder that religion in $\mathrm{BiH}$ is closely tied to the term "nation", where an individual is labeled as a member of a certain ethnic community based on his/her last or first name.

The second dimension considered under the statistical approach to the term "minority" is closely related to the time aspect. What it means is that, depending on the time of observation, a certain group, can be termed either a majority or a minority. If one observes a historical period or any other longer time stretch, it can be argued that demographic changes influenced by immigrations, wars, births, etc., can also create a situation in which a former majority became a minority. Here, again, we can examine the case of $\mathrm{BiH}$. If we look at the pre-war map of $\mathrm{BiH}$ from 1991 (see Map 1), we can observe an intricate network of different colors, each indicating one of the three ethnic groups (three major ethnic groups are relatively evenly spread across the entire territory).

$\mathrm{BiH}$ ), as they all fluently speak Bosnian/Serbian/Croatian when communicating with the rest of the population. 


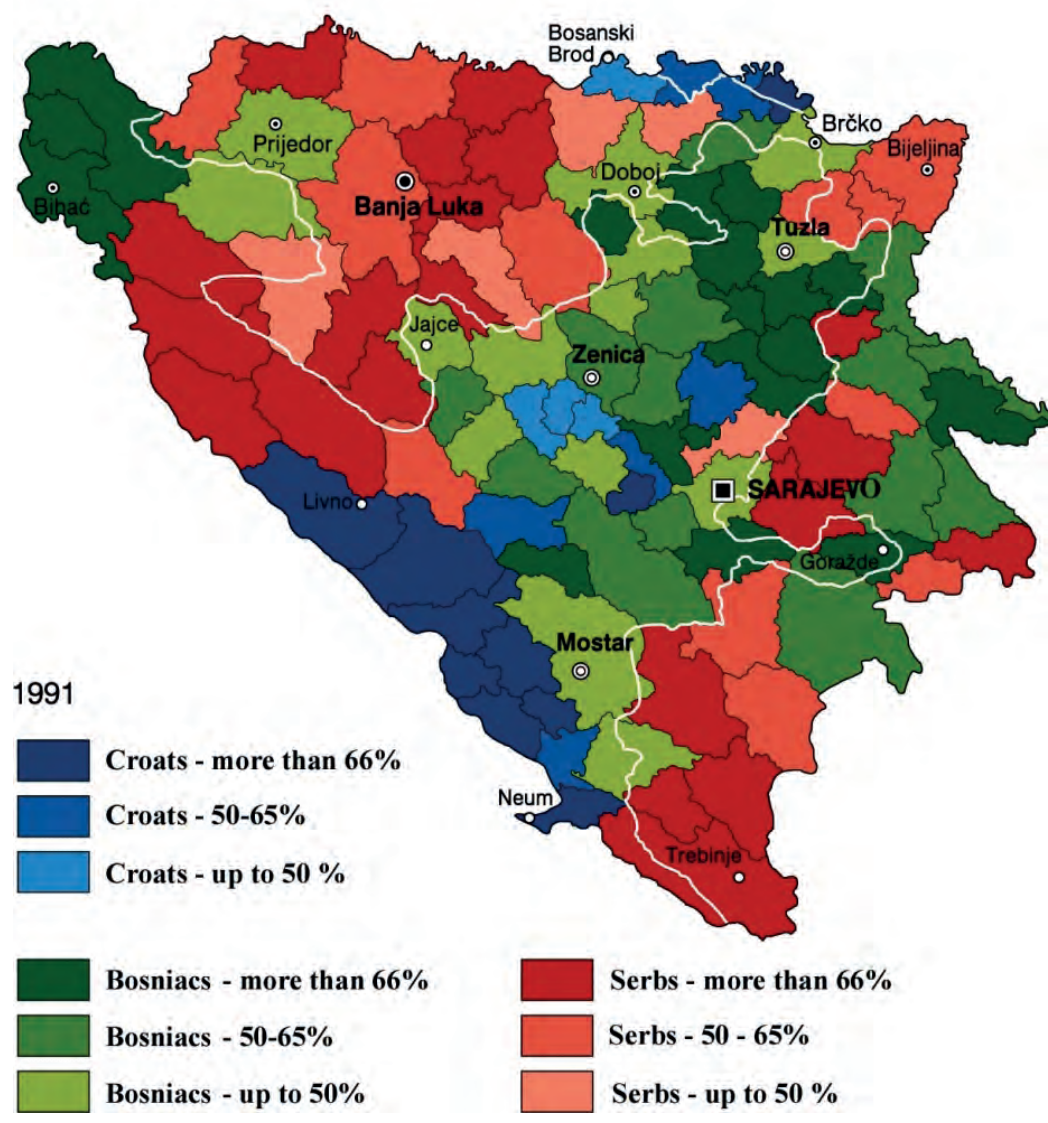

Map 1. Ethnic composition before the war in $\mathrm{BiH}$ (1991)

Source: Office of the High Representative (OHR), http://www.ohr.int/.

Examining the same map from post-1995 (see Map 2)7, we can notice a shift in colors, or delineate strict single color areas, which now designate many more majority areas and

${ }^{7}$ The white (IEBL) line represents a division line between the Croat-Bosnian Federation of $\mathrm{BiH}$ (51\% of the territory) and the Republic of Srpska ( $49 \%$ of the territory). This territorial division of the country was 
a very few mixed-color regions (three major ethnic groups have strict territorial presence, without major "island" spots. This is especially the case with the Serb group, which has no majority areas outside the territory of the Republic of Srpska).

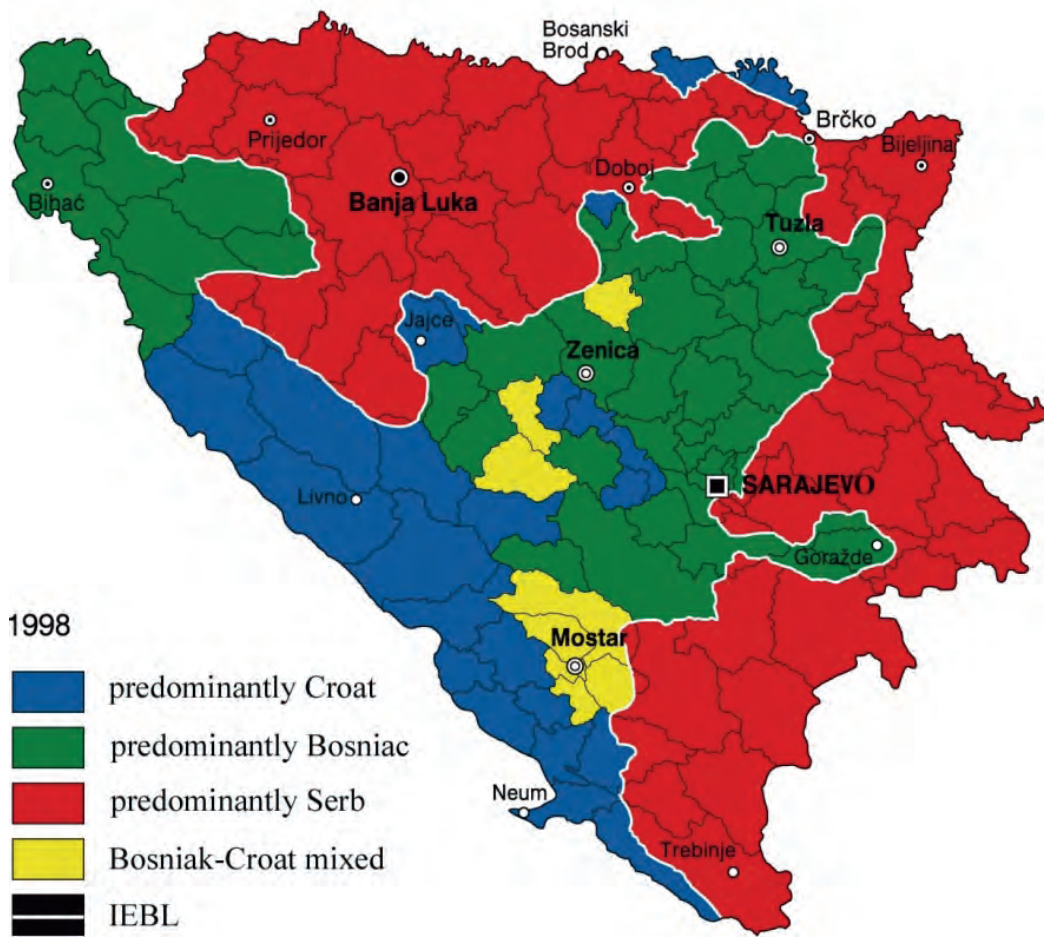

Map 2. Ethnic Composition of $\mathrm{BiH}$ in 1998

Source: Office of the High Representative (OHR), http://www.ohr.int/.

As it clearly stands, these time-relative changes were brought on by demographic changes induced by a war, thus

introduced by the 1995 peace settlement agreement known as the Dayton Peace Accords. 
influencing the long-term statistical representation of different ethnic groups across the country.

Lastly, the preceding dimension considered by the statistical approach, and the one that is essential in the case of BiH's internal stability, is territory, or spatial relativity. Edin Hodžić and Nenad Stojanović claim that person X can be a majority in his city, a minority in his region, and then again a majority in his country ${ }^{8}$. Illustrating this statement on the example of $\mathrm{BiH}$, and taking into account all previous statements, we can claim with certainty that in the case of $\mathrm{BiH}$ this is probably the most essential dimension of all. To clarify, let us observe the following scenario - a Croat woman who lives in Banja Luka is a minority in her city, because Banja Luka is overwhelmingly populated by the Serbs. She is also a minority in her region, because she lives in the Republic of Srpska (RS), where there is an insignificant Croat population. However, she is a majority in $\mathrm{BiH}$, her country, because the Constitution of $\mathrm{BiH}$ recognizes her as a majority or one of the three constituent groups, granting her equal rights to those who belong to the Serb or Bosniak majority, respectively.

\subsubsection{The Socio-Political Approach}

Despite an overwhelming relevance of the statistical approach, it is not necessarily the case that minorities are solely defined by statistical factors. To illustrate, we can consider the case of South Africa, where the black "majority" was considered a "minority" during the years of Apartheid. Hence, one can argue that territorial minorities in $\mathrm{BiH}$ (e.g. the Croats in the Republic of Srpska) can also be considered a socio-political

\footnotetext{
${ }^{8}$ Ibidem, p. 45.
} 
minority, although, this cannot be legally accepted due to the fact that on the state-level (not territorial - entity level), this group is a majority in a sense it enjoys all social, political and economic privileges granted to it by the Dayton Constitution. However, it can be concluded that in the case of $\mathrm{BiH}$, territorial (or statistical) minorities are also minorities in the socio-political context.

\subsubsection{The Constitutional Approach}

Despite the fact that a single group can be considered either a statistical or a socio-political minority (or both), it does not mean that it is a de jure minority. What it means is that under the Constitution of its state that particular group cannot be considered a minority. The reasons of this vary from state to state. When considering most East European states, we can say with certainty that these countries base their system on the principle of "the nation-state of a single nation", with constitutional recognition of specific minorities". In the case of $\mathrm{BiH}$, the term "nation-state" as such, cannot be applied, as there are not one, but three dominant nations. However, what we can talk about is the existence of de jure and de facto minorities. If we are to consider "solely"

${ }^{9}$ An example is the Republic of Croatia, whose Constitution states that the Republic of Croatia is hereby established as the national state of the Croatian people and a state of members of other nations and minorities who are its citizens: Serbs, Muslims, Slovenes, Czechs, Slovaks, Italians, Hungarians, Jews and others, who are guaranteed equality with citizens of Croatian nationality and the realization of ethnic rights in accordance with the democratic norms of the United Nations and countries of free world. Source: The Constitution of the Republic of Croatia, http://www.constitution. org/cons/croatia.htm. 
the constitutional approach, then we can say that territorial minorities in $\mathrm{BiH}$ are not de jure minorities; however, they can be deemed de facto minorities. Hence, this complex constellation causes a number of disputes, but with one predominant belief - territorial minorities in $\mathrm{BiH}$ do exist and mainly include Bosniaks and Croats living in Republic of Srpska. An alternative belief, although arguable, is that Serbs are a minority in the Federation of Bosnia and Herzegovina (FBiH). One way or the other, the opposing interpretations of the term "minority" have an enormous destabilizing effect in post-war BiH. Thus, what follows is an observation of the current destabilizing effects of minority discontent on present-day $\mathrm{BiH}$, which extends to two large realms - the power-sharing (political) and citizens' (social) realm.

\section{The Destabilizing Effects of Minority Discontent: From the Power-Sharing to the Citizen Realm}

\subsection{Why the Instability Scenario? The Effects of Statistical Data}

When the war ended in 1995, the results of the ethnic cleansing were annulled. This occurred primarily with the drafting of the Agreement on Refugees and Displaced Persons, outlined in Annex VII of the Dayton Peace Accords, whose Article I (1) states that: All refugees and displaced persons have the right freely to return to their homes of origin. They shall have the right to have restored to them property of which they were deprived in the course of hostilities since 1991 and to be compensated for any property that cannot be restored to them. The early return of refugees and displaced persons is an important objective of the settlement of the conflict in $\mathrm{BiH}$. 
The Parties confirm that they will accept the return of such persons who have left their territory, including those who have been accorded temporary protection by third countries ${ }^{10}$. Thus, the individuals who were forcefully displaced within the territory of $\mathrm{BiH}$ or refugees found on a territory of a third state now had a right to return to their pre-war homes. This is where statistics come into play and bring us to the issue of statistical minorities that $\mathrm{BiH}$ is dealing with even many years after the end of the conflict.

According to the data available from the United Nations High Commissioner for Refugees (UNHCR), approximately $50 \%$ of the pre-war 4.5 million people living in $\mathrm{BiH}$ was displaced from 1992 until 1995. Hence, the effects of the return process were partial, as most of the returning population did not settle in their pre-war territories ${ }^{11}$. By 2003, almost 1 million people returned (438,000 refugees and 547,000 displaced persons $)^{12}$, but most of them established in towns and villages where their particular ethnic group was in a majority. By the year 2000, the so-termed "minority return" process reached its peak, only to rapidly decrease 2 years later. When a set of constitutional amendments was adopted to the Constitution of Republic of Srpska (a sub-constitution in $\mathrm{BiH}$ ) in 2002, the Bosniaks and the Croats who returned to their pre-war homes in this entity, gained (as constituent peoples) equal rights to those of the Serb population. Thus, the ethnic discrimination of the Bosniaks and the Croats living in RS, which previously existed under the Dayton Constitution, was

${ }^{10}$ The General Framework Agreement, 1995. Annex 7. Agreement on Refugees and Displaced Persons, Article 1 (I), http://www.ohr.int/dpa/default.asp?content_id=375.

${ }^{11}$ See Map 2.

${ }^{12}$ Closing the Circle: From Emergency Humanitarian Relief to Sustainable Returns in South East Europe, UNHCR, 2004, http://www.unhcr.org. 
de jure over. The major aim of these new sub-constitutional provisions was to enhance the return process and achieve full affirmation of individual rights and freedoms on all levels of socio-political and economic life in $\mathrm{BiH}$.

Yet, there were some incontestable mistakes. Not only was the process termed "minority return" from the very beginning, thus labeling the constituent peoples as a de facto minority, but it contributed to the opposite process of "return", adding to the destabilization process which hit the entire country. No one desired to participate in "minority return", since the use of the term implicated severe discrimination on the basis of ethnicity and religion, mainly in the first 7 years after the conflict. This resulted in the creation of the previously portrayed ethnic cluster zones across $\mathrm{BiH}$, as those who did return did so by finding refugee in the places where their ethnic minorities and their ethnic political parties constituted a majority. This is precisely why $\mathrm{BiH}$ is burdened with the issue of statistical or territorial minorities. For example, despite the fact that $15 \%$ of Bosniaks and $5 \%$ of Croats ${ }^{13}$ returned to their pre-war settlements in the Republic of Srpska, these numbers are irrelevant when we consider the fact that most of the people returned just to renew their homes, but in reality live and work somewhere else. Thus, the seeming "equality" between majorities and territorial minorities in $\mathrm{BiH}$ occurs only on the highest executive, legislative and judicial levels, whose structure portrays the old ethno-national picture of 1991. And as distant as this power-sharing picture is from the current socio-political status and daily lives of territorial minorities across $\mathrm{BiH}$, it is still a source of destabilization that mostly penetrates these lower levels - the citizen's realm.

${ }^{13}$ Statistical Yearbook 2012, Republic of Srpska Institute of Statistics, http://www.rzs.rs.ba/front/article/271/. 


\subsection{The Entities - The Power-Sharing Realm as a Source of Destabilization}

At the time of the creation of the Dayton Peace Agreement, the term "entity" was deliberately chosen to delineate the non-state nature of the sub-national territories that were created by it, namely the Federation of $\mathrm{BiH}$ and the Republic of Srpska. Yet, both entities have developed into state-like systems, with their own presidents, governments, constitutions and judiciaries. Although the relations of both entities to the state level are symmetrical, we can say with certainty that the $\mathrm{RS}$ is, more or less, a system that resembles a unitary state. Its highly centralized structure and an almost ethnically homogenous population denote its unitary character. On the other hand, the FBiH looks more like a federal system, which, in reality, it is, since its federal organization comprises of 10 cantons ( 8 of which are almost ethnically homogenous and 2 others are mixed). However, these subnational units reflect the intricate ethno-territorial arrangement, but moreover emphasize the main ingredient of the post-war instability of $\mathrm{BiH}$ which is mirrored in the power-sharing realm between different groups. Let us note that in the power-sharing aspect of destabilization, the issue of territorial minorities is less important than in the citizens' realm, the reasons for which were outlined in the previous section. Nevertheless, what is relevant is that this realm deeply contributes to territorial minority discontent on the lower levels, an issue which will be discussed later in the study. But, going back to the issue of the diffusion of power, which, it is clear by now, sails from the center to the periphery, it is essential to pinpoint to the three major sources of destabilization which have their roots in this realm.

Firstly, we have to consider the fact that, in theory, $\mathrm{BiH}$ functions according to the principle of proportionality of 
political representation (including public service, political appointments, allocation of public funds, etc.). This would not be so problematic, were it not for the fact that in practice it is only the state (and not the entity) level that practices this rule. However, at the entity level, due to the fact that there are territorial minorities, the fact that RS declares itself a $n a$ tional state of Serbs and the fact that the FBiH recognizes the Bosniaks and the Croats as constituent peoples along with citizens, thus merging two opposing concepts of nation-state and national state and excluding the Serbs, creates a situation in which territorial minorities become underprivileged in political representation on the entity level. In terms of stability, this means that the three constituent peoples do not have the same rights when it comes to political influence on the entity level. Thus, unequal representation and low levels of influence by territorial minorities represent the foremost destabilizing effects whose roots stem from the power-sharing realm. Simply put, territorial minorities in both entities do not have the same rights as the majority living in that entity, despite the fact that on the state-level they are termed constituent peoples. The principle of proportional representation thus creates numerous political games, where one territorial minority or the other is used as a puppet representative. But this creates a false picture, while the real one is this - a severely undermined proportional political participation. This, in turn, opens up an array of possibilities for ethnic interplay which overshadow political agendas and keep the country's reform efforts behind the curtain of nationalistic discourses. All of this results in continuous instability of the already shattered political system, but even worse threatens the peace and reconciliation process among the common citizenry. The destabilizing effect of this scenario is currently most obvious in the preparations for the October 2013 population census. It is not a novelty that the Bosniaks 
living in RS have already started a campaign aimed at convincing people to register as Bosniaks, so that future statistics can result in a more or less similar ethnic picture that existed in 1991 (more Bosniaks present on today's territory of RS). The reasoning behind it - they do not want to be a territorial minority, but a fully equal group to the ethnic Serb majority living in this entity.

Furthermore, we must acknowledge the fact that all 3 groups (despite the differences in their territorial and statistical representation) enjoy a high degree of autonomy. This especially relates to issues that are not of common concern for all 3 groups, meaning that all responsibilities traditionally related to statehood (such as police), are dealt with on the entity level. Furthermore, due to a high degree of ethnic autonomy, there is a severe lack of will to strengthen the common state institutions. On the other hand, constitutional Article I (7) recognizes both state and entity citizenship, but without defining the meaning and relationship of these two conflicting concepts. This further strengthens ethnic autonomy on entity level and undermines the state. The result is a weak and unstable state and strong, ethnically divided entities. Thus, the destabilizing effect of this scenario is obvious. Nevertheless, the saga does not end here, but penetrates deeper into state's exclusive powers. This notably pertains to State's exclusive power on foreign policy, where the constitutional Article III (2a) states that The Entities shall have the right to establish special parallel relationships with neighboring states consistent with the sovereignty and territorial integrity of $\mathrm{BiH}^{14}$. Here, the reference is made exclusively to Croatia and Serbia, the "kin states" of Bosnia's two territorial minorities

${ }^{14}$ The General Framework Agreement, 1995. Annex 4. Constitution of $B i H$, Article III (2a), http://www.ohr.int/dpa/default.asp?content_id=372. 
(the Croats and the Serbs). How does this destabilize the state? First of all, this constitutional provision is a de facto Anschluss ${ }^{15}$, as it allows special and parallel relations with both states. This grants additional power to the entities to conclude treaties with both Croatia and Serbia. Many would argue that subnational regions (entities) in the modern federal states increasingly behave like independent international actors, but while this is true, $\mathrm{BiH}$ has a problem with drawing a clear line between constitutionally valid special parallel relations and those that affect the sovereignty of the state. These special relations allow provoke further destabilization in regards to the fact that certain territorial minorities (notably the Bosniaks living in the Croat and Serb majority areas) are constantly disadvantaged, as they do not receive different forms of support from a third state (kin state). This is especially valid in light of Croatian entry into the European Union, where it is expected that much financial aid will go to the region populated by the Croats in $\mathrm{FBiH}$, thus creating further economic disparities between different groups and destabilizing the citizens' realm in this entity.

The last, but probably the most destabilizing issue of all is the so-called "minority veto". The latter is used in cases of protection of vital interests of each group, and in theory should be used only as an emergency instrument in cases in which regular political consultations are unsuccessful. However, up till today, this instrument has been severely abused by all three groups. Jens Woelk claims that often the primary loyalty of political representatives in State-level institutions lies with the Entities, where the real power is exercised,

${ }^{15}$ J. Woelk, Federalism and Consociationalism as Tools for State Reconstruction? The Case of Bosnia and Herzegovina, [in:] Federalism, Subnational Constitutions and Minority Rights, ed. by G.A. Tarr, R.F. Williams and J. Marko, Westport-London 2004, p. 185. 
with the nation groups they represent, and - most important$l y-$ with the nationalist political party they represent ${ }^{16}$. What it means is that the power-sharing concept of "minority veto" can only further destabilize and weaken the state, leaving all power in the hand of the two entities, and creating further minority discontent as they find themselves struggling with pro-majority oriented decisions which, it is often the case, undermine particular rights of territorial minorities.

Thus, it is clear that these three power-sharing scenarios underpin ethnical divisions. However, the real effects of the above set-up are most obvious within the citizen's realm, influencing the well-being and everyday standards of ordinary men, who, most of all, feel the disadvantages of being territorial minorities. Hence, the following section will deal with the issue of how the power-sharing realm really influences those "minority" citizens, but more importantly analyze the sources of destabilization which derive from the lower sphere of the socio-political order.

\subsection{The Citizen's Realm as a Source of Destabilization}

In democratic countries, citizens can often pose a real threat to the central power, as citizen discontent and disobedience have historically succeeded in overthrowing leaders without legitimacy. Nevertheless, in countries of Eastern Europe, with weak democratic political culture and social inheritance of blind acceptance of political authorities, citizen discontent remains hidden within the walls of many homes, becoming permanent and only occasionally emerging as a form of a louder claim for rights. And as deeply imbedded in

${ }^{16}$ Ibidem. 
the society as it is, citizen discontent which remains unheard is often the most destabilizing factor within each society. Nowhere is this tendency more obvious than in $\mathrm{BiH}$, and to no one is it more characteristic than to its territorial minorities. What is more, each territorial minority has its own story, but as opposing as they might be, they all revolve around discriminating employment practices and unequal political representation on the entity level.

Although, the principle of equality of peoples living in two entities is outlined in both subnational constitutions, this provision is applied only on the highest levels of governance as to create a distorted picture which mirrors the pre-war situation of territorial representation. In reality and within the citizen's realm, this image is very different. The uneasiness of the situation of territorial minorities living across $\mathrm{BiH}$ is widely acknowledged by three different groups - ethnic political parties, religious communities, and only to a degree, the people themselves. With differing approaches to the issue of discrimination in representation, they construct stories within their own realms, but all agree on one aspect - the principle of equality between the Bosniaks, the Serbs and the Croats is a dead letter.

And indeed, when looking at the statistical data concerning the employment procedures and the number of territorial minorities employed within the public sector in the Republic of Srpska, the results are discouraging. The official data from the Agency of Public Service of RS indicates that in 15 ministries, 25 entity organizations, 6 entity directorates and the Secretariat of the Republic of Srpska, there are 5,029 employees. Out of this number, only 134 are Bosniak (2.66\%), 51 are Croat (1.01\%) and $32(0.63 \%)$ are "Others"17. However,

${ }^{17}$ E. Katana, Bez ekonomske perspektivnosti, 10.04.2013, „Mediaonline. ba“, http://www.mediaonline.ba/ba/?ID=511. 
the picture is even meeker at the lower levels of government. For example, out of 808 employees of the Tax Administration Office of the RS, only 6 are Bosniak, 6 are Croat, and 4 are members of national minorities (1 Slovenian, 2 Montenegrins and 1 Ukrainian) and 1 employee declared as "Other"18. The issue of discriminating employment practices, nevertheless, transcends the RS entity lines and is also characteristic of FBiH. This time, however, the focus is on the Serb territorial minority. Sarajevo, the capital of $\mathrm{BiH}$, is just one of the examples where the Serb population is discontent with the employment practices in state institutions. The president of the Helsinki Committee for Human Rights in BiH, Vera Jovanović, says that in the government of the Canton of Sarajevo, $96 \%$ of all employees are Bosniaks ${ }^{19}$. This is even more troublesome considering the fact that Sarajevo is not ethnically homogenous, but represents one of the few multiethnic cities in $\mathrm{BiH}$. The same problem troubles the predominantly Croat-populated Herzegovina, where only a few Bosniaks and Serbs work in the public sector. Hence, it is clear that the centrifugal force of ethnic politics leaves its mark on everyday life of common citizens. The dominant ethnic groups, saturated with stories of their own people's discrimination in areas where they represent themselves a territorial minority, use all the privileges of the leading position in their majority areas and create a situation in which one group is the ruler of all others, despite their equal constitutional rights and standing. And when a majority rules a minority, the latter are discontent for sure. However what even more dangerous, is the fact that such territorial minorities represent a threat to the country's

\section{${ }^{18}$ Ibidem.}

${ }^{19}$ S. Boračić-Mršo, Sarajevo: Pri zapošljavanju izgubljen duh multietničosti, 09.06.2011, http://www.slobodnaevropa.org/content/hrvati_i_srbi_ diskriminisani_u_sarajevu/24228645.html. 
internal stability, notably so in a post-conflict scenario where the groups in question are former belligerents.

Nevertheless, this is not where the story ends. The principle of equality of territorial minorities is endangered even if we look at symbols of local communities and institutions. To illustrate, let us use the examples of the Serb majority communities in the RS, all of which have their local religious holidays. Thus, all of the publically displayed symbols (notably coats of arms) carry religious symbols of only one group (here, the focus is mainly on the Serbs). This problem was acknowledged by the Constitutional Court of RS, when the Bosniaks initiated a legal procedure to remove these symbols in the cities of Vlasenica, Prijedor and Banja Luka ${ }^{20}$. However, despite a favorable ruling for the Bosniaks, this has not been done, but instead spurred major discontent among the territorial minorities living in these cities. As such, religious symbolism in areas where people are particularly sensitive to such issues, and where the authorities are not doing much to change the situation in favor of the disadvantaged groups, is a hot pot for future inter-ethnic clashes, and an unquestionable source of internal destabilization.

Thus, it is clear that the backdrop of ethnicity in the citizen's realm is pervasive, but also underpinned by the more pusillanimous aspects of the power-sharing realm. In fact, most of the destabilizing effects of the citizen's sphere have their roots in the latter. After all, the segregation that citizens experience in their day to day doings, from employment to cultural symbolism, and the discontent that results from it, raises a question regarding the future stability and unity of the state itself. In such

${ }^{20} 13$ legal claims were initiated across the RS. 
a context, a thought of a future conflict is not unreasonable, as we must not forget that whatever territorial minority group we are referring to in $\mathrm{BiH}$, one thing is in certain - the people justify these scenarios under the pretext that their groups are treated the same elsewhere. Thus, the discontent coming from the citizens' realm provides the support to the ethnically charged rhetoric of the power-sharing one from the inside, and consequently can be deemed the most powerful threat of all in the stability context of post-war $\mathrm{BiH}$.

\section{The Implications and Meaning of Territorial Minority Discontent for the Stability Context in $\mathrm{BiH}$ - Some Concluding Remarks}

Although they ended the war and created the conditions for stabilization of post-war $\mathrm{BiH}$, the Dayton Peace Agreement and particularly the Dayton Constitution, are certainly not the design for a stable and full functioning democratic state. The same can be claimed for Bosnia's subnational or entity constitutions, which flawlessly preserve inter-ethnic divisions, despite some great attempts at their reformation. This argument is easy to understand, considering many discriminatory aspects prescribed by both, the former and the latter. What is more, the fundamental contradictions imbedded in all three constitutions penetrate two different realms which influence the stability context of $\mathrm{BiH}$ - that of power-sharing and citizen levels. And while it is clear that many years after the signing of the Dayton Accords its founding principle based on the logic of accommodation of individual rights with those of nationalistic demands to preserve collective rights in 
"cleanse enclaves" ${ }^{21}$ clearly cannot work, it would be rather naive to think that the current consociational option is likely to be changed. The reasons for this are legion.

On the level of the power-sharing realm the status quo, characterized by talks of proportional distribution of seats, equality or better inequality of territorially underrepresented groups, endangered rights and ethnic quotas, remains unchanged for years. Thus, no wonder that most of the destabilizing effects and talks about strengthening the statuses of territorial minorities, stem precisely from this realm. To illustrate let us consider the following - even the items which so painfully cripple the current political agenda in $\mathrm{BiH}$, such as the Sejdić-Finci ${ }^{22}$ case, are burdened with talks of territorial minority rights, hence stirring the discussion of "national minorities" in the direction which aims only at strengthening the current already strong autonomy of the three constituent peoples on all levels of government. This is precisely the

${ }^{21}$ Implementing Equality: The "Constituent Peoples" Decision in Bosnia \& Herzegovina, (series: „ICG Balkans Report”, no. 128), SarajevoBrussels 2002, p. 25, http://www.crisisgroup.org/ /media/Files/europe/Bosnia\%2045.pdf.

${ }^{22}$ Jakob Finci (a Jew) and Dervo Sejdić (a Roma) initiated a claim against $\mathrm{BiH}$ claiming that the $\mathrm{BiH}$ Constitution was discriminatory on the base of race, religion and association with a national minority. Both plaintiffs made reference to Protocol 12 of the European Convention on Human Rights, which $\mathrm{BiH}$ signed on 1 April 2005. Initially, these were to separate cases, which were then merged into one by the European Court of Human Rights. It is interesting to note that neither Sejdic nor Finci claimed their rights before the signing of the European Convention on Human Rights on the part of $\mathrm{BiH}$, as they both believed that no legal basis for their complaints existed prior to this period. In December 2009 the Grand Chamber of the European Court for Human Rights ruled that BiH was guilty of violating Protocol 12 and Article 14 of the European Convention on Human Rights due to ethnic discrimination ingrained in its constitution. 
scenario which the power-sharing realm fears, thus flawlessly succeeding in avoiding any amendments which would (further) endanger their group statuses on all levels.

Furthermore, the other side of the spectrum, the citizens' realm, does not stay immune to such doings. In fact, this is the "influenced" realm, not the root of the issue. This influence is primarily mirrored in the fact that the status of territorial minorities, regardless of their ethnic background, remains unchanged, but heavily depends on the behavior of entity and state politicians. On the other hand, in instances of increased ethnic tensions, the discrimination between the majority and the territorial minority becomes more emphasized. Thus, it is not difficult to see how this lower-end realm, influenced by the upper, power-sharing one, becomes the root of yet another source of destabilization, and that is citizen discontent.

On the other hand, it cannot be negated that the ethnic distance between majorities and territorial minorities still exist across $\mathrm{BiH}$. What is more, this detachment is a direct product of the political system based on ethnicity, which was so enthusiastically praised at the time of creation of U5/98 judgment. Although the common citizens engage in joint social activities and gatherings, two decades of ethnicity-burdened politics create an unwanted distance between people, notably on the collective level. As recent research has shown, the distance present among groups is due to stereotypes that are often created by the behavior of those in the power-sharing realm - thus, the Bosniaks and the Croats living in RS are viewed as a potential threat to the Serbs, who in this case, are the good guys. One can simply reverse the territory, but the scenario still remains the same ${ }^{23}$. Thus, what lingers is the

${ }^{23}$ S. Puhalo, Etnička distanca $i$ (auto)stereotipi građana Bosne i Hercegovine, Sarajevo 2009, pp. 34-52. 
reality in which territorial minorities, wherever dispersed, have no real political power and exist on the margins within the majority society.

And as unfortunate as it might seem, the political environment in a divided $\mathrm{BiH}$ offers a few stabilization perspectives. Politicians are aware of the few gains that negotiation with the rivals will bring. Thus, the formula for the standard behavior is mutual avoidance and nationalistically inspired rhetoric directed at political rivals. All of this is exacerbated by artificial labeling of groups - terming them a minority despite their ultimate constitutionally granted rights to exercise political power and their majority status on the state level - thus creating a fruitful ground for preserving the unfortunate status quo. In divided societies, such as $\mathrm{BiH}$, the most leading political parties are ethnic parties. They have support of ethnic voters, who, history has shown, despite the obvious failures and obstructions that their respective ethnic parties have "achieved" in the past, still cast their votes for members of that particular party. After all, the alternative would be to vote for the rival party. Giovanni Sartori calls this polarized pluralism, where the logic of elections changes from one of convergence of policy positions to one of extreme divergence ${ }^{24}$. In $\mathrm{BiH}$, where there are a few and just recently emerged median parties, and even fewer median voters, the politics of extreme divergence has a stable ground. After all, why would its ground be shattered when it is fed by the politically induced destabilization from the power-sharing realm, but even worse, when it is preserved by the fear of "anything different" that so strangely rages among those artificially labeled minorities from the citizens' realm.

${ }^{24}$ B. Reilly, Democracy in Divided Societies. Electoral Engineering for Conflict Management, Cambridge 2001, p. 10. 